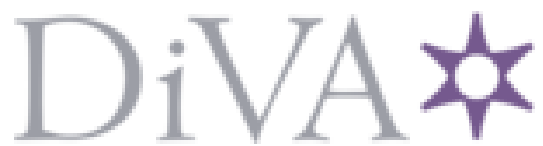

http://www.diva-portal.org

This is the published version of a paper published in Tourism Geographies.

Citation for the original published paper (version of record):

Conti, E., Heldt Cassel, S. (2019)

Liminality in nature-based tourism experiences as mediated through social media

Tourism Geographies

https://doi.org/10.1080/14616688.2019.1648544

Access to the published version may require subscription.

N.B. When citing this work, cite the original published paper.

Permanent link to this version:

http://urn.kb.se/resolve?urn=urn:nbn:se:du-30644 


\section{Tourism Geographies}

An International Journal of Tourism Space, Place and Environment

ISSN: 1461-6688 (Print) 1470-1340 (Online) Journal homepage: https://www.tandfonline.com/loi/rtxg20

\section{Liminality in nature-based tourism experiences as mediated through social media}

\section{Eugenio Conti \& Susanna Heldt Cassel}

To cite this article: Eugenio Conti \& Susanna Heldt Cassel (2019): Liminality in naturebased tourism experiences as mediated through social media, Tourism Geographies, DOI: $10.1080 / 14616688.2019 .1648544$

To link to this article: https://doi.org/10.1080/14616688.2019.1648544
(2) 2019 The Author(s). Published by Informa UK Limited, trading as Taylor \& Francis Group

Published online: 08 Aug 2019.

Submit your article to this journal $\llbracket$

Џلll Article views: 175

Q View related articles $\sqsubset$

View Crossmark data $₫$ 


\title{
Liminality in nature-based tourism experiences as mediated through social media
}

\author{
Eugenio Conti ${ }^{\mathrm{a}, \mathrm{b}}$ (D) and Susanna Heldt Cassel $^{\mathrm{a}}$ \\ ${ }^{a}$ Dalarna University, Falun, Sweden; ${ }^{b}$ Mid Sweden University, Östersund, Sweden
}

\begin{abstract}
The intersection between social media, liminality and naturebased tourism experiences hasn't been the focus of previous tourism research. Such intersection, on the other hand, is illustrative of how social media relate to the constitution and performance of tourism spatialities, tourist identities, storytelling and placemaking, and can lead to relevant theoretical contributes. We aim to investigate how liminality is expressed in relation to naturebased experiences by tourists on social media, and what role social media plays in mediating liminality during nature-based tourism experiences. The analysis is based on a participatory netnography of images and text posts, as well as online interviews with users of the popular social media Instagram. Findings show that the expression of tourism experiences in nature is closely related to specific notions of liminal otherness as opposed to the urban life and the everyday, where nature and wilderness are expressed as related to the genuine, the authentic and a true inner self. Creative combinations of pictures, captions and hashtags make it easier for tourists to express the contrast between the natural landscape and the everyday landscape once they returned home. These combinations also relate closely to performances of resistant and alternative selves and communities. At the same time, such performances are mediated and contested between freedom of self-expression, surveillance and social norms, an aspect that makes their liminal nature ambiguous.
\end{abstract}

\section{摘要}

社交媒体、阈限性与自然旅游体验之间的交叉领域，尚未成为旅 游硎究的焦点。另一方面, 这个交叉领域说明了社交媒体与旅游 空间的构成和展示、游客身份、叙事和地方营造之间的关系，并 可以产生相关的理论贡献。我们的目的是硎究游客在社交媒体上 如何表达自然体验方面的阈限，以及社交媒体在自然旅游体验中 对阈限的调节作用。这一分析基于对图片和文本帖子的参与式网 络民族志㸴究，以及对流行社交媒体Instagram（即时照片墙）用 户的在线访谈。㸴究结果表明, 旅游体验在自然中的表达与特定 的、迥异于城市生活和日常体验的阈限差异性概念密切相关，自

\section{ARTICLE HISTORY}

Received 30 September 2018

Accepted 19 July 2019

\section{KEYWORDS}

Liminality; liminal space; nature-based tourism; tourism experience; social media; Instagram;

netnography

关键词

阈限; 阈限空间; 自然 旅游; 旅游体验; 社交 媒体; 即时照片墙; 网 络民族志 
然和荒野被表达为与真实的、真正的和纯粹的内在自我相关。图 片、学幕和标签的创造性组合，让游客回到家后更容易表达自然 景观和日常景观之间的差异。这些组合也与抵抗的、另类的自我 社群的表演密切相关。与此同时，这些表演在自我表达自由、监 督和社会规范之间进行了调节和竞争，这使得它们的阈限性质变 得模糊不清。

\section{Introduction}

Several studies have found that tourism in nature provides sensations of amazement, peacefulness and awe. Nature is also perceived as a space in which identities are renegotiated through spiritual growth, introspection and psychological regeneration (Heintzman, 2009). A growing number of tourists are willing to engage in inspiring and transformational experiences in nature in an attempt to achieve different senses of self and connections to the environment; Newsome, Moore, and Dowling (2012) argued that these aspects are at the very essence of tourism in natural areas.

The constant flux of exchanging information online and formation of online communities in which such information finds hubs, particularly through social media, has contributed to the development of new spatial 'cultures and practices' in tourism (Munar, Gyimóthy, \& Cai, 2013, p. 2). This has dramatically affected not only how tourists experience places, but also how they actively construct them through personal stories, meanings and values (Ibid; Jaimangal-Jones, Pritchard, \& Morgan, 2010; Pritchard \& Morgan, 2006; Gyimóthy, 2013). On the other hand, if new virtual spaces of tourism (and the way such spaces relate with the physical ones) receive increasing attention in the tourism literature, it is also true that they have been investigated mostly to understand how they can be exploited by the tourism industry (Tribe \& Mkono, 2017). Although recent trends in nature-based tourism have suggested an increasing demand for the use of technology and mobile-based applications (Elmahdy, Haukeland, \& Fredman, 2017), studies by Dickinson et al. (2014), Dickinson, Hibbert, and Filimonau (2016), and Silas, Løvlie, and Ling (2016) have detected a perceived need to 'disconnect' from devices that dominate everyday life; this confirms dilemmas regarding the value of connectivity against a willingness to 'get away'.

However, a general advocacy and a post-positivist paradigm are still dominant, as are specific ontologies of technology (Munar et al., 2013; Lalicic \& Weismayer, 2016). Gyimóthy (2013) notes how, despite the multifaceted content conveyed by social media and Web 2.0-based technologies, much of the current research still tends to consider Web 2.0 as a space where human communication, decision-making and usage are driven by generalized and rational processes of information exchange. If it is true that Web 2.0 is enabling users to communicate 'the real experience revealed by real people' (Leung, Law, Van Hoof, \& Buhalis, 2013, p. 8), current and future research should adopt a more 'techspressive' view (Munar et al., 2013) and investigate the complex interactions between Web 2.0, tourism, place-making and identity, as expressed by complex user-generated narratives. By adopting critical and interpretive stances, as well as through innovative methodological approaches, the research in this field may be advanced (Ibid; Pink, 2013). 
This study departs from such premises in order to explore the intersection among social media, liminality and nature-based tourism experiences. This intersection can be potentially illustrative of how the digital spatiality of social media relates to the themes of tourist identity building, self-realization, storytelling and place-making. Starting from the studies of Van Gennep (1960) over rites of passage, liminal spaces have been conceptualized as spaces in which a transition from a condition to another, and from the known to the unknown, is experienced. Consequently, tourism journeys have been represented as rites of passage that enable tourists to experience liminality, by introducing them into a space 'other' than the tourist's daily lifeworld, which often carries transformational aspects related with disconnecting/detoxifying from the daily struggles and re-connecting with one's spirituality, health and well-being in a genuine environment, as well as performing different identities and building new communities of value (Jaimangal-Jones et al., 2010; Pritchard \& Morgan, 2006). Although studies have been produced about the intersection between tourism and liminality, no studies have been produced over a similar intersection between liminality, tourism and social media. Consequently, the paper's purpose is to explore expressions of liminality by tourists on social media, in relation to nature-based experiences, and how social media mediate liminality during nature-based tourism experiences. The analysis is based on a netnography of Instagram posts as well as online interviews with Instagram posters.

\section{Theoretical background}

\section{Liminality}

Liminality became a popular concept in the literature thanks to the studies of Arnold Van Gennep (1960) and the essays of Victor and Edith Turner (1974). Van Gennep used the term 'rites of passage' to label rituals accompanying a change in the individual or social status of a person, or even seasonal changes of entire societies. Such rites were distinguished in three phases: separation, transition and re-aggregation. The transition phase, which Van Gennep called the 'limen', was a phase characterized by a social ambiguity, in which the individual or the society was separated from a past social condition and yet not integrated into the new one. It was a sort of social and symbolic limbo in which, while transitioning from one condition to the other, most of the cultural and social rules, such as economical or legal ties, were modified or nullified (Van Gennep, 1960). Turner $(1974,1982)$ noted how this transition could be behavioral, symbolic, temporal and/or geographical, and underlined that it was characterized by a liberation from structural obligations proper of the social order, manifested through subversive and ludic events where people 'played' with the elements of the familiar and 'defamiliarized' them. 'Novelty emerges from unprecedented combinations of familiar elements' (Turner, 1974, p. 59), and an anti-structure born out of a liminal and free creativity comes to balance and transform the pre-existing structure of top-down norms and statuses (Bigger, 2009).

One of Turner's recognized merits was to draw several parallels between the indigenous societies studied during his fieldwork and post-industrial Western societies: such contextual expansion critically contributed, later, in making the concept of liminality popular across a variety of disciplines (Andrews \& Roberts, 2012; Wels, Van der 
Waal, Spiegel, \& Kamsteeg, 2011; Bigger, 2009; Thomassen, 2009, 2012). In the tourism literature, liminality has been used since Graburn (1978), often to define journeys, experiences, events, places and the tourists themselves. The concept has shown to be quite compatible with the tourism themes of escapism, transition and the carnivalesque: Tourists have been defined as liminal people who occupy an in-between state between spaces, times and social norms and who engage in journeys that bring them to distance from the old and within reach of the new (Burns, 1999; Jaimangal-Jones et al., 2010; White \& White, 2004; Urry, 2002). White and White (2004) underlined the desire of long-term travellers in the Australian Outback to escape routine, social pressure and responsibilities, as well as the quest for exploring different paths of personal growth. Studying participants of dance music events, Jaimangal-Jones et al. (2010) reached to similar conclusions, also adding the search for spiritual fulfilment, the need to see unfamiliar places, and the enjoyment of transitory encounters.

The spatial contexts of these studies have also been defined as liminal: transitional spaces, neutral limbos, whose strange characteristics provide an environment in which aspects of the tourists' identities can be reflected back in a different light, and in which normal conventions do not apply (Ibid; White \& White, 2004). Pritchard and Morgan (2006) explored the hotel as a liminal space, a ludic and unconventional site in which unusual rituals of romance and sexuality take place, old identities can be left aside, and new identities can be played with, constituted and performed. Similarly to the event stage and the Outback, hotels become spaces in which 'resistant bodies' (Shields, 1991) play and perform according to how they imagine themselves at the moment, suspending - even for a limited time - ranks, hierarchies and norms that would normally deny or limit these performances. Other studies associated similar qualities with the beach and seaside resorts (Shields, 1991). Generally, identities performed in these touristic liminal spaces can lead to bonding with new communitas, new and temporary communities characterized by the absence of rank, status and other normalized social structures that are present in everyday life (Ibid; Turner, 1974, 1982; White \& White, 2004). Jaimangal-Jones et al. (2010) noted how even in isolated areas travellers seek a kind of sociability that marks a nostalgic reference to a sense of lost or desired community. Again, being "in-between" social connections of the norm and the creation of new ones remarks the liminal qualities of the spaces, situations and experiences in which the tourist is situated.

\section{Nature-based tourism and liminality}

Natural areas such as forests or deserts have been explicitly associated with liminality by Jaimangal-Jones et al. (2010) and White and White (2004), who quoted Bridges (1996) in arguing that since pre-industrial times a person in transition would leave the village and go out into an unfamiliar stretch of forest to remain for some time, deprived of his or her own everyday identity and cultural landscape, a landscape 'other' and pristine in which 'a new sense of self could gestate' (2004, p. 12; see also Newsome et al., 2012).

Attempts have been made to produce broad definitions of nature-based tourism, depending on the kind of activity that is organized or sought in natural areas 
(Margaryan, 2017). These definition attempts also differ in terms of whether nature is the object or simply the setting of tourism consumption. This aspect led some authors to be cautious about including some forms of tourism within nature-based tourism, as in some instances they are closer to mass tourism (Newsome et al., 2012; Lindberg \& Lindberg, 1991). Yet, authors such as Buckley (2011), Mayer, Müller, Woltering, Arnegger, and Job (2010) and Goodwin (1996) include a vast array of tourism activities and motivations within the nature-based tourism spectrum. Although associations of nature with liminality are not always explicit in the literature about nature-based tourism, implicit similarities are commonly present across a variety of activities, motivations and orientations that tourists might have with regard to experiencing nature. This may be reflected in the dimension of 'being outside of the ordinary' that is present in one of the broadest definition attempts, that of Fredman, Wall-Reinius, and Grundén (2012, p. 3), who depict nature-based tourism as 'human activities occurring when visiting nature areas outside the person's ordinary neighbourhood'.

Vespestad and Lindberg (2011) extensive review of studies produced over naturebased tourism experiences confirmed that themes such as experiencing the extraordinary as a way of reaching new states of being, the seek for holiness and authenticity through the act of 'going back' to a landscape other and pristine, as well as the search to establish new communities of common values, are frequently emerging in the literature. Heintzman $(2003,2009)$ reviewed an extensive body of empirical studies on tourism and recreation in the wilderness and how they relate with spiritual growth and well-being. Introspection and spiritual growth were mostly present and associated with different activities across the majority of the studies presented. Spiritual experiences of this kind were mostly associated with being alone in the wilderness, but also with community-based adventurous activities such as canoe rafting. Of particular interest were the findings of Stringer and McAvoy (1992, in Heintzman, 2009), who made a clear connection between spiritual growth and the lack of constraints and responsibilities that one experiences in the wilderness, as well as the opposition of natural areas with the urban areas from which the tourists were coming.

\section{Critical perspectives on liminality, tourism and social media}

The concept of liminality has been subjected to criticism recently, particularly when it comes to the division between liminality and social constraint. As spaces get constructed by human beings, even liminal spaces are inevitably subjected to a degree of surveillance and scrutiny (Pritchard \& Morgan, 2006). Surveillance and scrutiny are noteworthy to mention especially in relation to the dramatic role that the new digital spaces have on human life. Kozinets (2015, p. 75 ) noted that, while online, people are both subjects and agents of a degree of surveillance and exhibitionism which is difficult to experience in the real world, a state that the author calls 'multi-panopticon'. This becomes a theme of interest when coupled with the increased ubiquity that mobile-based technologies grant to digital spaces, which introduce users to several creative activities and, at the same time, force them into constant connectivity with their everyday network (Dickinson et al., 2014). Wilhoit (2017) noted how social 
pressures to keep constant connectivity could jeopardize liminal spatialities normally associated with freedom, creativity and imagination.

Similar aspects should be further investigated in tourism as well. Smartphones allow tourists to engage in the pre- and post-phases during the core of the experience by a variety of means (Dickinson et al., 2014; Fotis, Buhalis, \& Rossides, 2011; Wang, Xiang, \& Fesenmaier, 2014). For instance, by using social media apps, tourists can keep their connection with peers at home while away (Munar et al., 2013). If social media and mobile applications increasingly blur the borders between the before and the after with the actual experience, one could question how this is reflected on the way tourists experience liminality, given that a 'connection' with the separation and the reaggregation is potentially never lost. Gretzel (2010) as well as Tribe and Mkono (2017), argued that this can affect the tourism experience by causing disengagement, disembodied experiences and a loss of sense of place, among other things. White and White (2007) and Silas et al. (2016) echoed this negative affection by underlining a conflicting tension between the act of going away, and breaking the routine, and the desire or need to maintain social interaction with the home environment. In agreement with these studies, Voase (2018) argued that smartphones force tourists to meet invasive expectations that can ultimately jeopardize any liminal separation phase that might relate to the tourism experience.

On the other hand, Wang et al. (2014) highlighted how mobile devices can provide tourists with a means to enhance creativity and spontaneity and to facilitate new interactions (see also Lamsfus, Wang, Alzua-Sorzabal, \& Xiang, 2015). Although Voase pointed at how geographical locations 'become irrelevant' (2018, p. 386), Hinton and Hjorth (2013) contended that mobile devices generate spaces that are not entirely online, as they can have a geographical baseline (through GPS-assisted applications, for example), placing them somewhere in-between online and offline, spaces that could indeed be argued to be liminal in nature, that are always accessible by users. Madge and O'Connor (2005) and Cappellini and Yen (2016) argued these to be liminal and empowering spaces, in which users can explore and perform contrasting and liberating identities, echoing, therefore, the considerations made by Pritchard and Morgan (2006) and Shields (1991).

\section{Instagram in tourism research}

According to Verkasalo, López-Nicolás, Molina-Castillo, and Bouwman (2010), it would currently be an oversimplification to draw clear distinctions between users and nonusers of smartphones; instead, it is important to distinguish between users and nonusers of specific smartphone-enabled services. One of the factors that users find to be most important in making use of a definite Web 2.0-based platform is the degree of control and customization that can be exercised over it, given a specific aim. This is arguably one of the reasons for the skyrocketing popularity of the social media Instagram, which currently has more daily users than Twitter (Abbott, Donaghey, Hare, \& Hopkins, 2013; Hu, Manikonda, \& Kambhampati, 2014). While being based on the apparently simple function of sharing pictures online, Instagram enables users to manipulate them through post-processing, visual filters and by including text captions 
and geotags. According to Abbott et al. (2013), this enables users to express emotions, reflections and contexts that may not be otherwise evident in the pictures. The connectivity opportunities offered by Instagram are wider than those available with Facebook. To begin with, one does not need to be followed back in order to follow another user and interact, which can be done by liking and commenting posts, as well as by instant-messaging through the 'Direct' feature (which is a tool for getting in personal contact with those posting images on Instagram). Moreover, in addition to sharing their content with their followers, users are able to share their posts to users outside their circle, by turning single words typed in a post into hashtags, tagging pages and other users, as well as sharing the post on other social media (Cuomo, Tortora, Festa, Giordano, \& Metallo, 2016; Fatanti \& Suyadnya, 2015). By connecting online photography with a more personalized expression of being in a specific place in a specific way, Instagram is capable of conveying personalized definitions of space, time, experiences and the way these connect with the user's identity, interpretation and imagination (Lo \& McKercher, 2015; Pink, 2006; Pearce \& Moscardo, 2015). For these reasons, in particular, Instagram was chosen to address the issue at stake.

Instagram is mentioned in tourism research in relation to issues such as sustainability and digital marketing (e.g. Gössling, 2017; Kaur, 2017; Királová \& Pavlíčeka, 2015). Yet few studies that focus on Instagram and/or online photography can be identified. Such studies depart largely from the dominant perspectives on technology described earlier, and explore exploitation potentials for tourism organizations, as well as the correlations between tourists' posts, destination image and consumption patterns (e.g. Stepchenkova \& Zhan, 2013; Rossi, Boscaro, \& Torsello, 2018; Latorre-Martínez, IñíguezBerrozpe, \& Plumed-Lasarte, 2014; Shuqair \& Cragg, 2017; Tenkanen et al., 2017). To the best of the author's knowledge, no study has so far been published on social media in relation to nature-based tourism besides Tenkanen et al. (2017). Most of the existing studies implement covert and/or quantitative data collection. Examples of notable exceptions are Fatanti and Suyadnya (2015), Baksi (2016) and Lo and McKercher (2015), who adopted photo-elicited interviews to deepen the understanding of posters' relationships with their posts.

\section{Research methodology}

Netnography is emerging as one of the most implemented methodologies for studies that relate with 'obtaining cultural understandings of human experience from online social interaction and content, and representing them as a form of research' (Kozinets, 2015, p. 17). Netnography has been praised for its immediacy, parsimony, and for its capacity to undertake unobtrusive data collection, as the researcher may access data without revealing his/her presence (Bartl, Kannan, \& Stockinger, 2016). However, removing disclosure from netnography also means eliminating the capacity to fully understand cultural meanings and contexts attached to content, and the possibility to authenticate, dispute or extend the researcher's interpretations (Kozinets, 2015; Mkono \& Markwell, 2014). As both these aspects were of primary importance in this study, participation was embraced in several data sources, which included online interviews, online observations and online document analysis, referred by Kozinets (2015) as 
elicited and archive data. Participation took place mainly through following pages and users, and by contacting users on Instagram Direct in the form of text-based chat interviews (Ibid; Salmons, 2014).

Most of the online observations were aimed to be external, meaning that they were not interfering with online communications of the users (Salmons, 2014). Following Kozinets (2015), disclosure was reinforced by making the researcher's identity clear and transparent at several levels: some information was added on the researcher's profile, and the research rationale was brought up several times during the online interviews. Emerging online interactions, even when not elicited, were coded though observational and reflective field notes (Kozinets, 2015) and were included in the findings when their content and/or the interaction with the researchers was judged to be appropriate given the research questions.

The data collection covered a period of approximately three months. An explorative approach was adopted (Salmons, 2014), which led to the final selection of a purposeful sample of 14 participants, with whom the researchers conducted a number of semi-structured online text-based interviews in English. Users were initially reached by using geotags of known national parks in Sweden. Participants encompassed different nationalities, including Swedish. The language of their posts was mostly English but included Swedish, German and Italian as well. Geotag-based data is considered as valuable when studying tourism spatialities and the way physical and digital spatialities relate with one another (Rossi et al., 2018). Geotags helped in assuring that relevant data was collected, given the research intent, as the researchers faced a lack of proper keywords (e.g. hashtags) which could help in distinguishing posts related with nature-based tourism experiences 'outside' the user's neighbourhood (Fredman et al., 2012). By typing the geotag of a given park on the Instagram search engine, the researchers were presented with all the posts created by Instagram's users with that geotag attached on his/her home feed. From there, a wide range of posts and user profiles could be assessed. The sample had a theoretical purpose, meaning that it was intentionally selected in order to obtain detailed data in relation to a given theoretical framework (Salmons, 2014). Consequently, the focus was on the appropriateness of the data rather than data generalization, and the sample was both emergent and critical, meaning that users were chosen as opportunities arose during the fieldwork, and selected based on how their characteristics could lead to rich data related to the advancing, understanding or explanation of the theoretical framework delineated above (Ibid; Patton, 2002). This meant that the final sample included users not selected according to the initial geotag input, and whose experience was located outside the initial National parks of reference. Further clarification was sometimes needed, during the interviews, regarding whether the post(s) examined were related to a tourism experience or not, as this aspect was a fundamental criterion in terms of inclusion/exclusion as the data collection proceeded.

General criteria established were: being an Instagram user and having post(s) whose visual and/or textual clues could suggest a degree of relevance with any aspect of liminality explained above. Therefore, the researchers' judgment over users' relevance started from the interpretation of visual and textual material that could be gathered from his/her posts (Willig, 2014). Nevertheless, the selection of participants tried 
to encompass users with different profile activities, (particularly in terms of number of posts, number of followers, number of likes/comments in a given post), as it was forecast that relevant data might have arisen from such differences. This was confirmed as the data collection proceeded. The final sample includes participants with more than $20 \mathrm{k}$ followers as well as less than 100, 'private' as well as 'public' profiles (meaning whether or not posts are accessible to users that do not follow the poster). Such aspects were not pre-determined systematic criteria, as it was judged that this would have threatened flexibility, potentially jeopardizing the discovery of information-rich data (Bryman \& Bell, 2011). Other criteria which might be drawn from the participants' profile (e.g. frequency of posts in a given timeline) were not considered as excluding criteria for similar reasons. A degree of subjective judgement was inevitably involved in such sampling design, as it normally is in qualitative research (Marshall, 1996).

\section{Findings and discussion}

These sections present and discuss the findings from the analysis. The first part contains examples of different ways in which liminality is expressed through Instagram and how posters explain and relate to their posts, as found in on-line interviews. The final part of the section discusses the conceptual and general aspects of the findings and draws conclusions based on the findings of the study.

\section{Opposing nature and the everyday: \#survival, dirtiness, poetry and zen}

The desire to escape routine and to transit into different or opposite zones, in which normal conventions associated with the daily life do not apply, has been linked to liminality in tourism by most of the reviewed studies (e.g., White \& White, 2004; Jaimangal-Jones et al., 2010; Pritchard \& Morgan, 2006). This aspect was noted in relation to several posts, in which a remarked opposition emerged between a lived or (imagined) daily space, connected with noise, stress, and commodities, and conversely a space connected with adventure, calm and survival. Instagram emerges as a digital spatiality that makes this opposition more visible, mainly through a relationship established between the picture and compelling text. This opposition was underlined by users. A caption in a post (a landscape photographed during a rainy sunrise) was explained as follows:

With the caption I want to point out that in order to have great experiences, it is an advantage to get out of the comfort zone. [...] I think that there is no bad weather, just the wrong clothing. I also think it is important to go outside and to reconnect with nature without all the noise, stress and distraction city life includes. That's what I try to show. (Greg, Sept. 3, 2018)

Another tourist, who posted a picture taken during a winter hiking event in Skuleskogen National Park, with the caption 'Of all the paths you take in life, make sure a few of them are dirt', explained the rationale behind the post in the online interview as follows:

It's good to occasionally tread off the beaten path, paved by 'modern-day expectations,' and go back to exploring. [The caption] sounds heavy, but basically just look up from all 
the screens and experience life around you, not to just live digitally and secluded. [...] people often say 'live life' but they don't. That's a shame. (San, Sept. 6, 2018)

Similarly, the desire to reach new states of being and seek holiness and authenticity through the act of moving into a landscape 'other' and pristine (Vespestad \& Lindberg, 2011; Heintzman, 2003, 2009) could also be noted, where these themes emerged by placing the 'otherness' of nature at the opposite of a stressful daily life. One poster included a poem by Emily Dickinson next to a set of pictures depicting a forest, which, for her before her audience, represent 'calm, silence, solitude. The Other from me, the non-human. Another language'. Thus, the poem:

sums up my sensations and what those pictures represent for me. That is, the affinity that one can feel when there is very little humanity around. Everything is in the beginning and in the end of the poem: I live fevered days, among lot of people. To take a day and to take yourself for a day elsewhere, without goals, without objectives to meet, to look, to listen and to feel ... at times it seems everything. (Clara, Aug. 21, 2018)

Similar feelings can sometimes be described just by one word, as exemplified by a poster whose one-word text caption - 'zen' - also expresses a space in which to disconnect, re-charge, meditate, where the poster is portrayed meditating while looking at a waterfall, immersed in the forest:

I find it important to disconnect and admire the moment, to cherish the beauty around us, because we are kind of caught in a stressing environment, everyone is in a hurry, agitated, running from one place to another and we forget to be happy. [...]l am a spiritual person, I practise yoga, love the nature. [... ] (Dina, Aug. 9, 2018)

The aforementioned themes can be related with a specific post that captures an emotion lived at the moment, but the relationship between intricate themes of personal growth, adventure and nature-based tourism experiences, and posts of reference, can be more complex and relate previously experienced spaces with new ones. Instagram leaves users free to reflect that in the way new posts relate to old posts. For example, one post portrayed a fountain in Tyresta National Park and included a critical reflection about technology, water and nature:

If technology is really about extending our abilities, well, then today this has more technology than my phone or the satellite it uses for locating my position. Never forget the importance of water in one's life. Close your tap earlier than you use to tonight. (text caption from an Instagram post by Alex).

During the interview, the user specified how his experience at Tyresta in relation to such reflection echoed a previous tourist experience he had in the desert, in which water was highly rationed. These feelings were evident in previous posts about that experience: 'the experience in the desert changed me somehow. Therefore, the post' (Alex, Sept. 2, 2018).

\section{Resistant bodies: liberation, animals and mythological creatures}

Performances of 'resistant bodies' take place in liminality when tourists feel free to imagine and play with new identities that challenge restrictions and norms proper of the daily life, even for a limited time (Pritchard \& Morgan, 2006; White \& White, 2004; 
Jaimangal-Jones et al., 2010). These performances can also lead to an alternate socialization, regardless of the restrictions that would be normally experienced. Through the same combination of captions and pictures mentioned above, Instagram facilitates the expression to those 'resistant bodies' that perform alternative ways of being in nature and being wild, given how they imagine themselves at the moment. Sometimes, the relationship with the theme of freedom from social constrains experienced in the daily life is evident, as explained in relation to some posts in which a poster poses without clothes, facing the wilderness:

It's a great sense of becoming more free! Men have sexualized my breasts all my life and I have felt used too many times! So I'm taking the right to show them without being used by men back! [...] It can be shown not as a cry for validation, but more of an assertion! Like, here I am! It's MY body, I am free! (Amy, Sept. 3, 2018)

These correlations of themes are made clearer by hashtags such as \#wilderness, and the included caption: 'To be fully human is to be wild [...] Wild is the soul where passion and creativity reside, and the quickening of your heart. Wild is what is real, and wild is your home'.

These performances can acquire an inedited and more complex strength thanks to Instagram's formatting options for posts and profiles. For instance, social norms and distinctions between animals and humans can be reversed: dogs can have Instagram profiles and speak about their experience in nature in first person, through text captions and comments. By talking through their dog's voice, dog owners are, as one online interviewee expressed, able to:

... express the bond between the human and the dog; that is a strong bond between us and getting even stronger through experiencing things together. [...] Taking moments of serenity in nature with them. [...] Our connection is strengthened by this.

[...] I also make it seem like he does this and that by himself, that he is more independent and can reason more human-like. (Lex, Sept. 4, 2018)

Tourists can move further by portraying themselves as magical beings, and the landscape they experienced can acquire magical features, through post-processing, descriptive texts, hashtags and even geotags. Thus, a mountain landscape can become 'Middle Earth' through typing it as a geotag that, despite not always being a clear expression of 'where am I', is certainly one of 'where I feel I am' or 'where I imagine to be' (Lo \& McKercher, 2015). Hashtags such as \#trollskog, \#oldgods, \#huldrefolk help to fixate qualities of a natural landscape as a gateway to another world. The relationship can acquire further expressive strength by bounding several posts or even entire profiles to the same thematization. This was particularly clear in posts associated with paganism, or with profiles associated with fantasy impersonators. Users can label themselves as elves, fairies and witches to further express a distinct connection with places that they find suitable to be able to perform and play with such identities.

Although it might be interpreted as such by an external observer, these are not alternative identities performed in nature for the sake of Instagram itself, or for visibility, and nor is Instagram the only space in which such identities exist. For instance, one poster described herself as an 'elven warrior', a 'proud ravenclaw' and a 'part-time knight', and uploaded pictures in which she performs as a medieval warrior, an elf or 
a druid. And yet, throughout the interview, she specified that 'my Instagram is about 'this is who I am', and not 'this is who I am aspiring to be" (Eve, Sept. 5, 2018). Although she made it clear that she does not need social media for her self-expression, the interviewee sees Instagram as a space through which she can allow people to see parts of her life that she chooses to display (Eve, Sept. 5 2018). Many posts in her profile express closeness to nature as something mystical and spiritual, as exemplified by this caption: 'for when you walk amongst trees you may as well find questions you didn't know existed.'

Another poster, Uva depicts herself, through post-processing modifications and a caption, as a tailed 'skogsrå' (a mythological creature of the Nordic folklore). She explained:

My profile is a product of what I love and how I experience nature and see it. [...]lt is who I am and what I love and how I love to express myself the best; otherwise I think I would have run out of ideas by now if that was not who I am [...] I feel very close to the tales of huldrefolk and many times I wondered if me myself is under a huldre spell because of my extreme love for roaming the woods. (Uva, Sept. 5, 2018)

Uva depicted several natural areas located between Norway and Sweden according to the themes mentioned above, and connected with the sacral, paganism and mythological creatures through text captions, post-processing and hashtags.

I am myself very inspired by my old folklore of trolls, giants, fairies, etc. And the magical aspects of nature that goes hand in hand with me being a heathen, so for hashtags I think it is very connected. [...] my captions are what I feel and think and how I experience the woods with a hint of magic. (Uva, Sept. 5, 2018)

In all the above examples, Instagram does not emerge as a realm in which separate identities can exist, but rather as a space in which these identities can be performed, played with, re-imagined and expressed in a peculiar way. In this sense, Instagram provides an additional means to express the poster's creativity (Wang et al., 2014). It could be, as in the case of Lex, that the performance is close to what Madge and O'Connor (2005) defined as 'new selves', because the performance implies identifying oneself with a different being and, as will be shown further below, to new communities that transcend normally experienced bounds and roles. However, it is also true that, as Eve stated, what is performed on Instagram and what is performed in real life can exist more as a hybrid, without clear borders (lbid), or as a performance that amplifies and/or reflects a liminality experienced in real life (Cappellini \& Yen, 2016).

\section{Transitioning}

Transition lies at the very core of the concept of liminality (Thomassen, 2012). The act of 'transitioning' can be identified in at least two different dimensions. The first is a transition in the real world between an urban and daily-life landscape and nature, in which a new dimension is embraced and the daily life is left aside, demarcated by a sharp opposition, as shown above. The very nature of many Instagram posts is openly 'in-between' the urban and the natural, in which often the first is criticized, or separated from, and the second one celebrated. Several participants underlined how this opposition existed, even when it was not as immediately clear from the post as others, 
and was a meaningful part of their experience in the nature that they wanted to communicate. Here, Instagram is a space of free expressivity.

At the same time, another spatiality introduced by Instagram itself (and the mobile device that grants access to Instagram) is present when a visitor 'transits' from their real-life experience of a place into his/her user experience in the digital world. This transition was found to be uneasy, although it is 'technically' made easy by the device, because the digital realm of Instagram comes to be melted with the real-life experience in the nature, an aspect that the users considered with caution. All of the users interviewed chose their posts once they were back at home, or at least far from the nature experience that they were living in their real life, as they did not want their experience of a landscape 'other' and rich of meanings (later expressed through their Instagram posts) to interfere with their digital space. This also makes the expressions and the mediation of experiences and emotions staged, not only in terms of editing of photos but also in the context of post-reflection and post-experience narrations, allowed through Instagram (Abbott et al., 2013).

Generally, users did not mention significant issues or difficulties experienced in coping with transitioning from Instagram to the real world. However, one user accompanied the following caption to one of her posts:

It's very important for me to find moments and things that bring me some peace. I've found that simple, productive household activities, reading, and being offline actually are quite helpful for me. [...]. I feel like I'm moving past that [Instagram], making room for other things in life that are more important to me right now, such as mental peace and rest, schooling, a healthy and happy life and relationships with the people around me. (text caption from an Instagram post by Lae)

Lae, whose profile counts around 8500 followers, further explained the caption during the interview by stressing the sensation of addiction that she experienced when posting on Instagram: 'the more I distance myself from It, the more it tires me' (Lae, Sept. 4, 2018).

\section{Communitas: pages, comments, followers}

Instagram provides users with many tools to connect with pages and other users, and to interact through comments and messages. Pages with a specific theme - like 'forest' ('let's get lost in the trees') 'divine_forest' ('let's get lost in the divine forest'), or 'norsewarriors' (a 'Viking community' from Asgard) - can be followed or tagged in order for a post to be included in their profile page, which in turn can generate comments or new followers. Some of the tourists interviewed appeared as followers of some of the aforementioned pages.

Even hashtags play an important role because they are not only keywords that help make a meaning clear, but also a link, that makes the image searchable through the Instagram engine. Users can even follow specific hashtags, as well as other users and pages, in order to make them visible in their feed. The existence of a specific 'audience' of reference is remarked by the participants, to whom the question of whether or not to use hashtags means being free to define specific audience and interactions, but also being free to connect with a specific selection of likeminded 
people, pages, or even specialized journals. On the contrary, Dina considered showing what is important for her, and specifically for the post showed above: 'the idea was disconnecting, and by using hashtags I would connect again. [...] I would alter the picture by adding a couple of hashtags' (Dina, Aug. 9, 2018).

Across these disparate cases, it is important to note that users can choose freely the audience that they refer to, and that such choice is related with a particular way of being in a place that they transmit through the picture, whether this is well-being, silence, dirtiness, survival, mythological creatures or other 'dogs on Instagram'.

The communities generated by these mechanisms are liminal in the sense that they are joined, tagged or connected with one another by dynamics that can be different from the ones experienced in the daily life (White \& White, 2004; Bigger, 2009). Even when users do not claim to follow specific groups or pages that relate with the themes of their profile, the idea of sharing and commenting their experience with others is important, just as it is important to interact through comments and to follow people who share similar interests.

\section{Surveillance and commercialization}

Many examples have been provided of Instagram's usability to play with one's idealized identity and experience of a place, as well as to perform oppositions with the user's daily life. These echo the characteristics of what Turner labelled the 'anti-structure' proper of liminality (Turner, 1974). Yet, caution should be taken in seeing a sharp binomial dichotomy between structure (out of Instagram) and anti-structure (Instagram). Specifically, the nature of Instagram as an area in which one can observe a 'dissolution of normative social structure' (Ibid, p. 70) is ambivalent. This aspect was elaborated by participants in different ways and particularly highlighted by the researchers' netnographic notes.

Posters are aware of the double nature of social media and the different roles they take on in real life versus on social media. At the same time, they reflect on the sometimes superficial quest for popularity. Popularity is a complex and vast topic that could only be touched here, yet still deserves a mention in the context of how the liminal aspects of creativity, freedom, and the forging of new communities relate with the perceived conformism, commoditization, and loss of authenticity. \#instalike, \#instafollow \#instagood are some of the most popular hashtags that users apply to posts of a vast array of nature, although they have been criticized by many Instagram marketing practitioners for their excessive conformism: hashtags 'empty' of content, placed by users on posts due to a mainstream opinion that doing so makes the post more popular and visible. Nevertheless, such hashtags are used, and it is important to investigate the elements of standardization and conformism to a 'structure' that they trigger in otherwise creative and personal posts. Most of the users (particularly Dina and Clara, less than 400 followers) placed being popular and visible for the sake of it at the opposite of the way they express themselves, even by using hashtags. Lae (around 8500 followers) found it important to state: 'I've grown super, super-tired of the community and all these people being self-obsessed and playing popularity games. It's really all a big lie, I think' (Lae, Sept. 4, 2018). 
Yet, an important aspect elaborated from the researcher's netnographic notes was that when a user posted a picture with the hashtags mentioned above, it could lead to websites of companies that sell items related to camping, tour operators, professional photographers, or influencers, starting to follow the user. Accessing these pages/followers instantly brings promotional messages, which are either visually noticeable in the profile thanks to the profile branding or by the text included in the description.

Businesses that have an Instagram page can connect with users of interest as easily as was the case for the researchers, by following them and interacting with them through tags, comments, and messages. What is important to notice here is that, although a minimal degree of control is available for the user by deciding whether or not to 'follow back', an initial contact - however desirable - is possible. Such initial contact, even in the case of not following back, can lead to deeper interactions through messages, comments (which can range from a simple like to comments under posts such as 'follow my page', or even be more explicitly promotional) over which the user has little control.

Moreover, as is the case for social media such as Facebook, Instagram is run by ads, and the algorithm behind each user's timeline selects specific typologies of ads that might be interesting for the user, and position these ads in between the user's timeline. The researchers themselves could observe this particular aspect when, once related pages (regarding topics such as outdoorism, paganism, and forest therapy) were followed, ads with branding related to these pages (hiking equipment, clothes, craftsmanship, etc.) were repeatedly shown while scrolling the timeline. The resemblance of the posts in the ads to those spontaneously generated by the users was remarkable. Finally, market-based logics interfered in one case in which the very user, as well as posting in relation to her travels and experiences with nature, started using his/her profile for business reasons. As mentioned by Uva, whose profile counts more than 24,000 followers: 'How I express myself is just how Ive always expressed myself, but I think I tweak it a bit. [...] I think more about what I write since I want to sell' (Uva, Sept. 5 2018).

Two key aspects are here revealed. First, a theme of surveillance, both algorithm and popularity-based (Pritchard \& Morgan, 2006; Kozinets, 2015). Second, a commercialization of a space whose capacity to foster the users' creativity and freedom to perform an alternative self was explained above. In other words, an intrusion of norms proper of the 'structure' (Turner, 1974), identified in the everyday neo-liberal economy, marketing and consumption, into what ideally should be an 'anti-structure' in which users are free to 'play with' idealized identities and enhanced expressions of otherness, made of \#survival, \#detox, \#mothernature, \#norrfolk, etc.

\section{Conclusions}

Findings have shown that the way in which liminality is expressed through the use of Instagram in relation to nature-based tourism experiences is about defining and expressing personal and social identity, but also about the transcending of borders between the self and the persona on Instagram in relation to nature. It is also about 
the staging of experiences through the post-processing of images and the adding of hashtags and geotags, which make the posts stand out and enhance their expression. The expression of tourism experiences in nature is closely related to specific notions of difference and otherness, as opposed to the urban life and the everyday, where nature and wilderness are expressed as related, for example, to the genuine, the authentic and the true inner self. The combinations of pictures, captions and hashtags were able to express more easily the opposition between the natural landscape and the everyday landscape.

Thus, Instagram offers a space in which the tourist can 'play' with symbolic tools in order to reflect on his/her own experience and deliver a message, whether this is a message of opposition among survival, adventure and comfort, or among stress, crowds and other social pressures as opposed to freedom, silence and meditation. Moreover, 'resistant bodies' are able to use Instagram's expressive tools and socialization platforms to perform parts of themselves alternative to the social norm and engage in a kind of sociality (through comments, followers and pages) that reflects such performance. In this way, Instagram enhances tourists' creativity in expressing a way of living the nature that contrast with standardized social pressures.

On the other hand, it is worth mentioning the co-presence of standardized logics proper of popularity-seeking, business and marketing, as well as the sometimes problematic nature of transitioning between Instagram and the real-life experience, which question the liminal qualities of Instagram. It could be noted that the posting on Instagram is closely related to popularity and the commercial and marketing purposes of businesses, which become intertwined with the communities and connect commercial messages with the posters and their emotions in sophisticated ways. This could be seen as a form of liminal space between the personal/emotional and the commercial.

It is true that some of the findings can somewhat blur the distinction between creative expressions of liminality and the intrusion of social and cultural pressures and norms, making the liminal nature of Instagram's performances ambiguous. Going back to 'classical' photography, Bourdieu and Whiteside (1996) had already noted how images taken by a specific individual inevitably carry a dramatic heritage of social norms and pressures about where the camera should aim. Pink (2006) argued that although these norms play certainly a role, it is important to caution against the reduction of individual creativity to collective norms and account for the individual creativity and innovation, specifically when related to individuals' unique biographies and skills. The present study provides important evidence in this sense, as both users' creativity and biographies can be seen in what they convey through their posts, whose purpose, according to their statements, does not relate with social pressures of visibility, but with the perceived need to express parts of their biography, even though the former pressure can sometimes be tangible. Nevertheless, it is still possible to be introduced to non-liminal elements of commoditization, marketing and consumption through targeted ads, posts, and users' activity.

As this is an exploratory study that was conducted with a somewhat limited sample, it is important to acknowledge certain limitations. Further research is needed on the issues raised by the findings and corroborated by several participants. For 
instance, a more detailed segmentation of the users of reference could be applied in order to identify important differences and similarities across different genders, generations or backgrounds. This study is widely based on data related to the post-phase of the tourism experience (both posts and reflections on the posts), and further research could add value by focusing on the relationship between nature-based tourism, liminality and social media by engaging in field-based methods. Other popular social media platforms, such as Twitter and Facebook, should be investigated with similar intents. The way these platforms relate with one another could also lead to new understanding of how new digital spatialities intersect with tourists' experience of places, identity building and place-making aspects that have only started to be uncovered here.

\section{Notes on contributors}

Mr Eugenio Conti is a PhD candidate in Tourism studies at Mid Sweden University, and research assistant at Dalarna University, Sweden. He is a member of CeTLeR (Center for Tourism and Leisure Research) and ETOUR (European Tourism Research Institute). Mr Conti's current areas of research are tourism experience, experience value, tourism social media and naturebased tourism.

Prof. Susanna Heldt Cassel is a professor of cultural geography at Dalarna University, Sweden, head of CeTLeR (Center for Tourism and Leisure Research), and supervisor of master and PhD students at Dalarna University, Mid Sweden University and Uppsala University. Prof. Cassel's areas of research are rural tourism, mobility and destination development in peripheral areas, with a focus on social sustainability, identity and cultural heritage.

\section{ORCID}

Eugenio Conti (D) http://orcid.org/0000-0003-1763-140X

Susanna Heldt Cassel (D) http://orcid.org/0000-0002-4919-4462

\section{References}

Abbott, W., Donaghey, J., Hare, J., \& Hopkins, P. (2013). An Instagram is worth a thousand words: An industry panel and audience Q\&A. Library Hi Tech News, 30(7), 1-6.

Andrews, H., \& Roberts, L. (Eds.). (2012). Liminal landscapes: Travel, experience and spaces inbetween. London: Routledge.

Baksi, A. (2016). Destination bonding: Hybrid cognition using Instagram. Management Science Letters, 6(1), 31-46. doi:10.5267/j.msl.2015.12.001

Bartl, M., Kannan, V. K., \& Stockinger, H. (2016). A review and analysis of literature on netnography research. International Journal of Technology Marketing, 11(2), 165-196. doi:10.1504/ IJTMKT.2016.075687

Bigger, S. (2009). Victor Turner, liminality, and cultural performance. Journal of Beliefs \& Values, 30(2), 209-212. doi:10.1080/13617670903175238

Bridges, W. (1996). Making Sense of Life's Changes. London: Nicholas Brealey Publishing.

Bryman, A., \& Bell, E. (2011). Business research methods. Oxford: Oxford University Press.

Buckley, R. (2011). Tourism and environment. Annual Review of Environment and Resources, 36(1), 397-416. doi:10.1146/annurev-environ-041210-132637

Bourdieu, P., \& Whiteside, S. (1996). Photography: A middle-brow art. Stanford: Stanford University Press.

Burns, P. M. (1999). An introduction to tourism \& anthropology. London: Routledge. 
Cappellini, B., \& Yen, D. A. W. (2016). A space of one's own: Spatial and identity liminality in an online community of mothers. Journal of Marketing Management, 32(13-14), 1260-1283. doi: 10.1080/0267257X.2016.1156725

Cuomo, M. T., Tortora, D., Festa, G., Giordano, A., \& Metallo, G. (2016). Exploring consumer insights in wine marketing: An ethnographic research on\# Winelovers. Psychology \& Marketing, 33(12), 1082-1090. doi:10.1002/mar.20942

Dickinson, J. E., Ghali, K., Cherrett, T., Speed, C., Davies, N., \& Norgate, S. (2014). Tourism and the smartphone app: Capabilities, emerging practice and scope in the travel domain. Current Issues in Tourism, 17(1), 84-101. doi:10.1080/13683500.2012.718323

Dickinson, J. E., Hibbert, J. F., \& Filimonau, V. (2016). Mobile technology and the tourist experience: (Dis)connection at the campsite. Tourism Management, 57, 193-201. doi:10.1016/j.tourman.2016.06.005

Elmahdy, Y. M., Haukeland, J. V., \& Fredman, P. (2017). Tourism megatrends, a literature review focused on nature-based tourism. MINA fagrapport 32, Norwegian University of Life Sciences.

Fatanti, M. N., \& Suyadnya, I. W. (2015). Beyond user gaze: How Instagram creates tourism destination brand?. Procedia - Social and Behavioral Sciences, 211, 1089-1095. doi:10.1016/j. sbspro.2015.11.145

Fotis, J., Buhalis, D., \& Rossides, N. (2011). Social media impact on holiday travel planning: The case. International Journal of Online Marketing, 1(4), 1-19. doi:10.4018/ijom.2011100101

Fredman, P., Wall-Reinius, S., \& Grundén, A. (2012). The nature of nature in nature-based tourism. Scandinavian Journal of Hospitality and Tourism, 12(4), 289-309. doi:10.1080/15022250.2012. 752893

Goodwin, H. (1996). In pursuit of ecotourism. Biodiversity \& Conservation, 5(3), 277-291.

Gyimóthy, S. (2013). Symbolic convergence and tourism social media. In A. M. Munar, S. Gyimóthy, \& L. Cai (Eds.), Tourism social media: Transformations in identity, community and culture (pp. 55-71). Bingley, UK: Emerald Group Publishing Limited.

Graburn, N. (1978). Tourism: The sacred journey. In V. L. Smith (Ed.), Hosts and guests: The anthropology of tourism (pp. 21-36). Oxford: Blackwell.

Gretzel, U. (2010). Travel in the network: Redirected gazes, ubiquitous connections and new frontiers. In Post-global network and everyday life (pp. 41-58). New York: Peter Lang.

Gössling, S. (2017). Tourism, information technologies and sustainability: An exploratory review. Journal of Sustainable Tourism, 25(7), 1024-1041. doi:10.1080/09669582.2015.1122017

Heintzman, P. (2003). The wilderness experience and spirituality what recent research tells us. Journal of Physical Education, Recreation \& Dance, 74(6), 27-32. doi:10.1080/07303084.2003. 10609216

Heintzman, P. (2009). Nature-based recreation and spirituality: A complex relationship. Leisure Sciences, 32(1), 72-89. doi:10.1080/01490400903430897

Hinton, S., \& Hjorth, L. (2013). Understanding social media. London: Sage Publications Ltd.

Hu, Y., Manikonda, L., \& Kambhampati, S. (2014). What we Instagram: A first analysis of instagram photo content and user types. In Proceedings of the 8th International Conference on Weblogs and Social Media, ICWSM 2014 (pp. 595-598). Menlo Park, CA: The AAAI Press.

Kaur, G. (2017). The importance of digital marketing in the tourism industry. International Journal of Research - Granthaalayah, 5(6).

Királová, A., \& Pavlíčeka, A. (2015). Development of social media strategies in tourism destination. Procedia - Social and Behavioral Sciences, 175, 358-366. doi:10.1016/j.sbspro.2015.01. 1211

Kozinets, R. V. (2015). Netnography: Redefined. London: Sage Publications Ltd.

Jaimangal-Jones, D., Pritchard, A., \& Morgan, N. (2010). Going the distance: Locating journey, liminality and rites of passage in dance music experiences. Leisure Studies, 29(3), 253-268. doi:10. 1080/02614361003749793

Lamsfus, C., Wang, D., Alzua-Sorzabal, A., \& Xiang, Z. (2015). Going mobile: Defining context for on-the-go travelers. Journal of Travel Research, 54(6), 691-701. doi:10.1177/0047287514538839

Lalicic, L., \& Weismayer, C. (2016). The passionate use of mobiles phones among tourists. Information Technology \& Tourism, 16(2), 153-173. doi:10.1007/s40558-015-0042-z 
Latorre-Martínez, M. P., Iñíguez-Berrozpe, T., \& Plumed-Lasarte, M. (2014). Image-focused social media for a market analysis of tourism consumption. International Journal of Technology Management, 64(1), 17-30. doi:10.1504/IJTM.2014.059234

Leung, D., Law, R., Van Hoof, H., \& Buhalis, D. (2013). Social media in tourism and hospitality: A literature review. Journal of Travel \& Tourism Marketing, 30(1-2), 3-22. doi:10.1080/10548408. 2013.750919

Lindberg, K., \& Lindberg, K. (1991). Policies for maximizing nature tourism's ecological and economic benefits (pp. 20-21). Washington, DC: World Resources Institute.

Lo, I. S., \& McKercher, B. (2015). Ideal image in process: Online tourist photography and impression management. Annals of Tourism Research, 52, 104-116. doi:10.1016/j.annals.2015.02.019

Madge, C., \& O'Connor, H. (2005). Mothers in the making? Exploring liminality in cyber/space. Transactions of the Institute of British Geographers, 30(1), 83-97. doi:10.1111/j.1475-5661.2005. 00153.x

Margaryan, L. (2017). Commercialization of nature through tourism (Doctoral Dissertation, Mid Sweden University).

Marshall, M. N. (1996). Sampling for qualitative research. Family Practice, 13(6), 522-526. doi:10. 1093/fampra/13.6.522

Mayer, M., Müller, M., Woltering, M., Arnegger, J., \& Job, H. (2010). The economic impact of tourism in six German national parks. Landscape and Urban Planning, 97(2), 73-82. doi:10.1016/j. landurbplan.2010.04.013

Mkono, M., \& Markwell, K. (2014). The application of netnography in tourism studies. Annals of Tourism Research, 48, 289-291. doi:10.1016/j.annals.2014.07.005

Munar, A. M., Gyimóthy, S., \& Cai, L. (Eds.) (2013). Tourism social media: Transformations in identity, community and culture. Bingley, UK: Emerald Group Publishing.

Newsome, D., Moore, S. A., \& Dowling, R. K. (2012). Natural area tourism: Ecology, impacts and management (Vol. 58). Bristol: Channel View Publications.

Patton, M. Q. (2002). Qualitative research and evaluation methods. California EU: Sage Publications Inc.

Pearce, J., \& Moscardo, G. (2015). Social representations of tourist selfies: New challenges for sustainable tourism. In: Conference Proceedings of BEST EN Think Tank XV (pp. 9-73). Skukuza, Mpumalanga, South Africa.

Pink, S. (2006). The future of visual anthropology: Engaging the senses. London: Routledge.

Pink, S. (2013). Doing visual ethnography. London: Sage Publications Ltd

Pritchard, A., \& Morgan, N. (2006). Hotel Babylon? Exploring hotels as liminal sites of transition and transgression. Tourism Management, 27(5), 762-772. doi:10.1016/j.tourman.2005.05.015

Rossi, L., Boscaro, E., \& Torsello, A. (2018). Venice through the Lens of Instagram: A Visual Narrative of Tourism in Venice. In Companion of the Web Conference 2018 on the Web Conference 2018 (pp. 1190-1197). International World Wide Web Conferences Steering Committee.

Salmons, J. (2014). Qualitative online interviews: Strategies, design, and skills. London: Sage Publications Ltd.

Silas, E., Løvlie, A. S., \& Ling, R. (2016). The smartphone's role in the contemporary backpacking experience. Networking Knowledge: Journal of the MeCCSA Postgraduate Network, 9(6), 40-55.

Shields, R. (1991). Places on the Margins. London: Routledge.

Shuqair, S., \& Cragg, P. (2017). The immediate impact of Instagram posts on changing the viewers'perceptions towards travel destinations. In 1st International Conference on Advanced Research (ICAR-2017), Manama, Bahrain.

Stepchenkova, S., \& Zhan, F. (2013). Visual destination images of Peru: Comparative content analysis of DMO and user-generated photography. Tourism Management, 36, 590-601. doi:10. 1016/j.tourman.2012.08.006

Tenkanen, H., Di Minin, E., Heikinheimo, V., Hausmann, A., Herbst, M., Kajala, L., \& Toivonen, T. (2017). Instagram, Flickr, or Twitter: Assessing the usability of social media data for visitor monitoring in protected areas. Scientific Reports, 7(1), 17615. doi:10.1038/s41598-017-18007-4 
Thomassen, B. (2009). The uses and meanings of liminality. International Political Anthropology, 2(1), 5-27.

Thomassen, B. (2012). Revisiting liminality: The danger of empty spaces. In H. Andrews, \& L. Roberts (Eds.) Liminal landscapes (pp. 37-51). London: Routledge.

Tribe, J., \& Mkono, M. (2017). Not such smart tourism? The concept of e-lienation. Annals of Tourism Research, 66, 105-115. doi:10.1016/j.annals.2017.07.001

Turner, V. (1974). Liminal to liminoid, in play, flow, and ritual: An essay in comparative symbology. Rice Institute Pamphlet - Rice University Studies, 60(3).

Turner, V. W. (1982). From ritual to theatre: The human seriousness of play. New York: Paj Publications.

Urry, J. (2002). The tourist gaze (2nd ed.). London: Sage.

Van Gennep, A. (1960)[1908]. The rites of passage. Chicago: University of Chicago Press.

Verkasalo, H., López-Nicolás, C., Molina-Castillo, F. J., \& Bouwman, H. (2010). Analysis of users and non-users of smartphone applications. Telematics and Informatics, 27(3), 242-255. doi:10. 1016/j.tele.2009.11.001

Vespestad, M. K., \& Lindberg, F. (2011). Understanding nature-based tourist experiences: An ontological analysis. Current Issues in Tourism, 14(6), 563-580. doi:10.1080/13683500.2010. 513730

Voase, R. (2018). Holidays under the hegemony of hyper-connectivity: Getting away, but unable to escape?. Leisure Studies, 37, 384-395 doi:10.1080/02614367.2018.1475503

Wang, D., Xiang, Z., \& Fesenmaier, D. R. (2014). Adapting to the mobile world: A model of smartphone use. Annals of Tourism Research, 48, 11-26. doi:10.1016/j.annals.2014.04.008

Wels, H., Van der Waal, K., Spiegel, A., \& Kamsteeg, F. (2011). Victor Turner and liminality: An introduction. Anthropology Southern Africa, 34(1-2), 1-4. doi:10.1080/23323256.2011.11500002

White, N. R., \& White, P. B. (2004). Travel as transition: Identity and place. Annals of Tourism Research, 31(1), 200-218. doi:10.1016/j.annals.2003.10.005

White, N. R., \& White, P. B. (2007). Home and away: Tourists in. Annals of Tourism Research, 34(1), 88-104. doi:10.1016/j.annals.2006.07.001

Wilhoit, E. D. (2017). My drive is my sacred time': commuting as routine liminality. Culture and Organization, 23(4), 263-276.

Willig, C. (2014). Interpretation and analysis. In The SAGE handbook of qualitative data analysis (pp. 136-149). London: Sage. 